\title{
Implementation of Group Counseling using Cognitive Restructuring Techniques to Enhance Career Maturity of Dayah Inshafudin High School Students in Banda Aceh
}

\author{
Sulma Mafirja ${ }^{\left.{ }^{*}\right)}$, Siti Zahra Bulantika ${ }^{2}$ \\ ${ }^{1}$ Universitas Islam Negeri Ar-Raniry Banda Aceh, Indonesia \\ ${ }^{2}$ Universitas Raden Intan Lampung, Indonesia \\ Corresponding author, E-mail: sulmamafirja07@gmail.com
}

\begin{abstract}
The purpose of this study was to determine the implementation of Group Counseling by using cognitive restructuring techniques to enhance the Career Maturity of students at SMA Dayah Inshafudin Banda Aceh. The method used in this study was quasiexperimental with a one-group pretest-posttest design. The subjects in the study were eight students who had low levels of self maturity. Data collection techniques in this study used the Self-Scale or CMI (Career Maturity Inventory). The results showed that the career maturity of students could be improved by using group counseling using cognitive restructuring techniques, as evidenced by the results of data analysis using Wilcoxon different tests, from the pretest and posttest results obtained z-output $<$-table $(z=-2,527$; $\mathrm{p}=.012$ ). The conclusion in this study is that student career maturity can be improved by group counseling services using cognitive restructuring techniques.
\end{abstract}

Keywords: cognitive restructuring, career maturity, group counseling

\section{Introduction}

Problems that often occur in the period or process of adolescent development are related to issues in the educational environment, both formal and informal. And the question that often arises is when students enter a period where they are required to be able to develop in following changes that occur, such as in the teaching and learning process, students often experience problems related to learning activities both at the elementary, junior high or high school / vocational level. Also, during high school / vocational school, students are required to have to be able to have a deeper understanding related to the career that will be undertaken or traveled when they will finish in high school / vocational school.

Students often experience problems related to career decisions and career maturity. Super believes that the success and readiness of adolescents to fulfill related tasks that are contained in each stage of career development is called career maturity (Bravo, Seibert, Kraimer, Wayne, \& Liden, 2017). Furthermore, career maturity as a level where the individual has mastered the task of career development, both the knowledge and attitude components, which are following the stage of career development (Chan et al., 2015).

Career maturity, namely attitudes and competencies that contribute to career decision making. These attitudes and skills support the determination of the right career decision. Career maturity is also a reflection of the individual career development process to increase the capacity to make career decisions (Johnston, 2018). Career maturity is also an affective and cognitive readiness of the individual to overcome the developmental tasks that are confronted with it. Affective preparation consists of career planning and career exploration, while cognitive readiness consists of decision-making abilities and insight into the world of work. Conceptually, career maturity is obtained if the individual succeeds in completing a series of developmental tasks continuously from every stage of life.

A person's career maturity is also influenced by age (Harlow \& Bowman, 2016). Suitability to age as intended in this definition is based on the theory of Life-Span, Life-Space from Super, 
which says that every individual at a certain age has a role that must be carried out following the stages of development. Life-Span Theory and Life-Space from Super, which says that there is a relationship between the stages of psychological life and social role theory to get a general picture of a multi-role career. Life span is the stage of career development that is played according to age, from being a child, studying, living in the community, working, getting married to retirement related to the social conditions in which the individual lives.

Super classifies the factors that affect career maturity into five groups. The five elements referred to are as follows: (a) Bio-social factors; (b) Environmental factor; (c) Personality; (d) Vocational factors; (e) Individual achievements

In the research "Development of Career Selection Guidance Information Material to Improve Career Decision Making Ability of Vocational School Students Career Vocational School Economics" shows the results that career selection guidance information is useful to improve students' career decision-making abilities (Lestari \& Supriyo, 2016). Students show differences in career decision making abilities when before and after being given career guidance information materials where the career decision making the ability of students increases after being given career selection guidance information.

This is consistent with research on youth career selection. According to his research teens who do not have clear career choices tend to have emotional and personality disorders such as pessimism, anxiety disorders, and negative self-concepts and low self-esteem (Kim \& Kim, 2016).

Based on the researcher's initial observations, the problems that are often and are being experienced by students at Dayah Inshafuddin High School are related to career maturity, where children seem unable and lack of confidence in determining what career they will choose to continue their education in college or work, and students also still feel confused about the purpose of the career selection.

The first thing to do is to change the mindset of negative thinking related to the importance or lack of career maturity that students have, will be changed to a more positive mindset that students will be more aware of and understand that career determination and selection is very important, so they are required to be more sensitive, understanding and mature in choosing a career. One way to provide changes related to students' mindset to have more high career maturity is through group counseling using cognitive restructuring techniques. In connection with efforts to improve adaptability, cognitive restructuring techniques have advantages that can be seen in studies of several studies that have been done before. The research uses cognitive restructuring to reduce academic procrastination behavior (Saputra, Purwanto, \& Awalya, 2017).

Furthermore cognitive restructuring to reduce body dysmorphic disorder among adolescents (Edmawati, Hambali, \& Hidayah, 2018). Other studies using cognitive behavior therapy techniques can reduce social anxiety in students (Bulantika, Wibowo, \& Jafar, 2018), As in this study using group counseling with approaches derived from cognitive behavior therapy, in addition to other studies that explain that the Rational Emotional Behavioral restructuring group has a significant effect on improving the mental health level of parents of exceptional children. Based on some of the research above, this cognitive restructuring technique is hypothesized that Group Counseling using effective cognitive restructuring techniques to enhance the career maturity of Dayah Inshafudin Banda Aceh High School students.

\section{Method}

The research that will be used in this research is pre-experiment with one group pretestposttest approach. The experiments carried out are experiments conducted on one group only without the comparison group, so in this study, it is assumed that the difference between initial and final measurements is the effect of the existence of a treatment. The subjects of this study were 8 (eight) grade XI students of Natural Sciences 1 who had low levels of career maturity.

Data collection techniques in this study are using career maturity scale or CMI (Career Maturity Inventory), in this study, the psychological scale used is to reveal students who have low career maturity. This CMI scale is given to research subjects when doing pre-test and post-test. The CMI scale is used to show students who have low and high career maturity levels. After the spread of the CMI scale is done, it will get students who have low career maturity. 
Based on the development of the data instruments used, need to be done Validity Test and Reliability Test. To facilitate the calculation, SPSS 23 is used. It is known that the instrument used is valid with a sig level of 0.05 and a CMI scale reliability value of 0.73 . The data can also be normally distributed with Asymp values. Sig. (2-tailed) $=.961$. Furthermore, the statistical analysis technique used to test the hypotheses in this study is the Wilcoxon Test method. In the Wilcoxon test, were not only the markers noticed but also the magnitude of the difference before and after the treatment was carried out.

\section{Results and Discussions}

The data collected in this study is about the Implementation of Group Counseling by using cognitive restructuring techniques to enhance the career maturity of Dayah Inshafudin Banda Aceh High School Students. The subjects in this study were students of class XI IPA 1, of which there were eight students who had low career maturity. The eight students will be made into 1 group in participating in group counseling activities using cognitive restructuring techniques to enhance student career maturity.

The research data was obtained with the help of instruments in the form of a Career Maturity Inventory (CMI) scale adopted from (Savickas \& Porfeli, 2011). The results of the study explained that there were significant differences before and after participating in group counseling activities to improve student career maturity. These results can be seen in table 1:

Table 1. Test Results for Improving Student Career Maturity From the Results of Pretest and Posttest

\begin{tabular}{|c|c|c|c|c|c|c|}
\hline Griup & Pretest & & Postest & & $\mathbf{z}$ & Sig \\
\hline & $\mathrm{M}$ & $\mathrm{Sd}$ & $\mathrm{M}$ & $\mathrm{Sd}$ & & \\
\hline CR & 50.62 & 2.97 & 86.75 & 3.57 & -2.527 & .012 \\
\hline
\end{tabular}

The implementation of group counseling by using cognitive restructuring techniques to improve the career maturity of students based on the results of table 1 . it can be explained that the value of pretest $(\mathrm{M}=50.62, \mathrm{Sd}=2.97$; ) obtained is much lower compared to after being treated in the form of group counseling with cognitive techniques restructuring, and the posttest score obtained is a much higher level of student career maturity compared to before treatment $(\mathrm{M}=$ $86.75, \mathrm{Sd}=3.57 ; \mathrm{z}=-2.527 ; \mathrm{p}=.012)$. Can also be seen from the results of Graph 1 below:

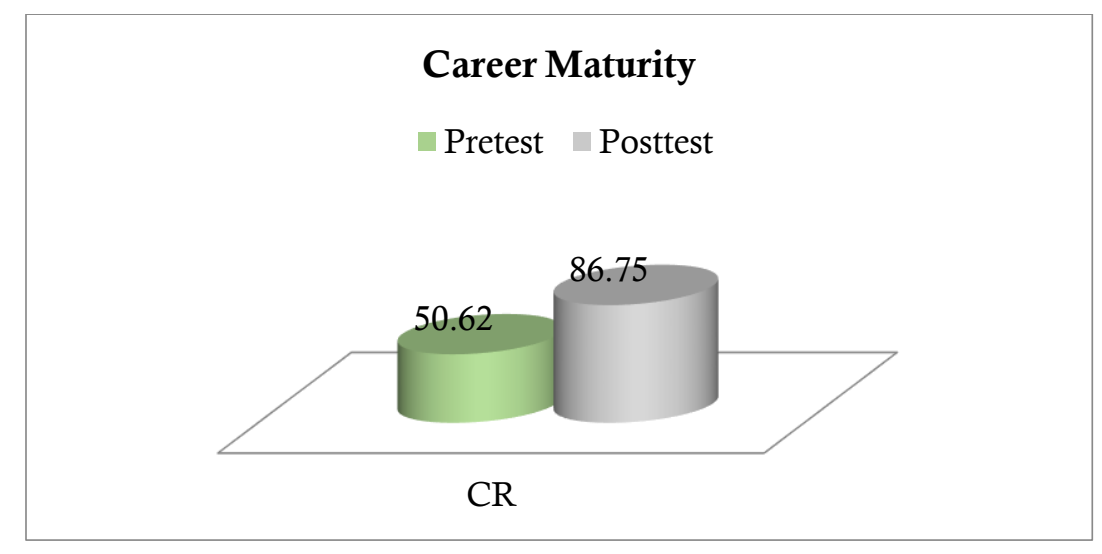

Graph 1: Career Maturity 
The results of the study explained that there was a significant difference between before and after being given treatment in the form of group counseling using cognitive restructuring techniques to improve the career maturity of students in SMA Dayah Inshafuddin Banda Aceh. In line with the research which says that group counseling with cognitive behavior therapy is effective in helping students overcome career problems, about this research in the therapeutic cognitive approach there are several techniques, one of them being cognitive restructuring techniques used in this study (Jabbar, Purwanto, Fitriyani, Marjo, \& Hanim, 2019). Furthermore, other research states that cognitive restructuring techniques can help students in career decision making (Ayuningtyas, Wibowo, \& Purwanto, 2019), supported by research that says that cognitive behavior therapy approaches help students in Nigeria overcome negative thoughts on careers (Ogbuanya et al., 2018).

The rationale used in cognitive restructuring is an attempt to strengthen the belief that the client 1) can affect performance, and intrapersonal communication 2) precisely thoughts that are self-harming or negative self-statements can cause emotional disturbances and interfere with performance, a process which then repeats in cycles. Associated with career maturity, career maturity is the affective and cognitive readiness of the individual to overcome the development tasks that are confronted with him, due to biological, social development, and expectations of the people who have reached that stage of development. Affective readiness consists of career planning and career exploration, while cognitive preparation consists of decision-making abilities and insight into the world of work. Therefore, cognitive restructuring techniques can provide confidence in thinking about career decisions following the task of personal development.

\section{Conclusions}

This research was conducted to see the implementation of group counseling with cognitive restructuring techniques to improve the career maturity of students at SMA Dayah Inshafuddin Banda Aceh. The results of the study showed group counseling with cognitive restructuring techniques was effective in increasing student career maturity. There is a difference in the results of the career maturity scale or CMI before being treated in the form of group counseling using cognitive restructuring techniques and after being given treatment. Furthermore, the use of service goals that are not the same or heterogeneous is suggested to be able to prove the effectiveness of the implementation of group counseling services with cognitive restructuring techniques for broader results in increasing student career maturity.

The results of this intervention are expected to be a stepping stone by further researchers to perfect various limitations in the research process, so it is recommended to further researchers to focus more on several groups, not just 1 group, but also make a comparison with control groups. And in the use of techniques, it is also advisable to use several methods so that the results of the research can be better, especially to improve student career maturity.

\section{Acknowledgments}

Thank you to colleagues who helped with the research, as well as the principal, Dayah Inshafudin Banda Aceh High School counselor who has permitted to research at school

\section{References}

Ayuningtyas, I. P. I., Wibowo, M. E., \& Purwanto, E. (2019). Group Counseling with SelfInstruction and Cognitive Restructuring Techniques to Improve Career Decision-Making Self-Efficacy. Jurnal Bimbingan Konseling, 14-19.

Bravo, J., Seibert, S. E., Kraimer, M. L., Wayne, S. J., \& Liden, R. C. (2017). Measuring career orientations in the era of the boundaryless career. Journal of Career Assessment, 25(3), 502-525.

Bulantika, S. Z., Wibowo, M. E., \& Jafar, M. (2018). Group Counseling with Systematic Desensitization Techniques and Thought-Stopping Techniques to Reduce Social Anxiety. Jurnal Bimbingan Konseling, 7(2), 106-112.

Chan, K. Y., Uy, M. A., Moon-ho, R. H., Sam, Y. L., Chernyshenko, O. S., \& Yu, K.-Y. T. (2015). 


\section{KONSELING: Jurnal Ilmiah Bimbingan dan Konseling}

Vol.1, No.2, Januari 2020

Available online: https://journal.ilininstitute.com/konseling

Sulma Mafirja ${ }^{1}$, Siti Zahra Bulantika

Comparing two career adaptability measures for career construction theory: Relations with boundaryless mindset and protean career attitudes. Journal of Vocational Behavior, 87, 22-31.

Edmawati, M. D., Hambali, I. M., \& Hidayah, N. (2018). Keefektifan Konseling Kelompok dengan Teknik Cognitive Restructuring untuk Mereduksi Body Dysmorphic Disorder. Jurnal Pendidikan: Teori, Penelitian, Dan Pengembangan, 3(8), 1076-1079.

Harlow, A. J., \& Bowman, S. L. (2016). Examining the career decision self-efficacy and career maturity of community college and first-generation students. Journal of Career Development, 43(6), 512-525.

Jabbar, A. A., Purwanto, D., Fitriyani, N., Marjo, H. K., \& Hanim, W. (2019). Konseling Kelompok Menggunakan Pendekatan Cognitive Behavior Therapy (CBT) untuk Meningkatkan Kematangan Karir. Jurnal Selaras: Kajian Bimbingan Dan Konseling Serta Psikologi Pendidikan, 2(1), 35-46.

Johnston, C. S. (2018). A systematic review of the career adaptability literature and future outlook. Journal of Career Assessment, 26(1), 3-30.

Kim, S.-H., \& Kim, M.-J. (2016). The effect of career preparation program on self-esteem, selfefficacy related career decision-making and career development readiness in university students. Journal of Digital Convergence, 14(4), 407-418.

Lestari, D., \& Supriyo, S. (2016). Kontribusi Minat Jurusan, Kualitas Layanan Informasi Karir, dan Pemahaman Karir terhadap Kemampuan Mengambil Keputusan Karir. Jurnal Bimbingan Konseling, 5(1), 47-54.

Ogbuanya, T. C., Eseadi, C., Orji, C. T., Anyanwu, J. I., Ede, M. O., \& Bakare, J. (2018). Effect of rational emotive behavior therapy on negative career thoughts of students in technical colleges in Nigeria. Psychological Reports, 121(2), 356-374.

Saputra, R., Purwanto, E., \& Awalya, A. (2017). Konseling Kelompok Teknik Self Instruction dan Cognitive Restructuring untuk Mengurangi Prokrastinasi Akademik. Jurnal Bimbingan Konseling, 6(1), 84-89.

Savickas, M. L., \& Porfeli, E. J. (2011). Revision of the career maturity inventory: The adaptability form. Journal of Career Assessment, 19(4), 355-374. 